\title{
Expanding corporate finance perspectives to equity crowdfunding
}

\author{
Silvio Vismara ${ }^{1}$ (D)
}

Received: 11 October 2021 / Accepted: 15 October 2021 / Published online: 15 November 2021

(C) The Author(s), under exclusive licence to Springer Science+Business Media, LLC, part of Springer Nature 2021

\begin{abstract}
In equity crowdfunding, firms raise capital online from a large pool of heterogeneous investors, thereby providing primary market opportunities similar to traditional public markets, such as initial public offerings. The development of secondary markets is instead still limited, making the post-offering perspectives of both crowdfunding investors and firms closer to private equity deals. We believe that equity crowdfunding markets provide an interesting setting where to test existing corporate finance and financial economics theories, as well as to develop new theoretical insights. Relatedly, our understanding of crowdfunding mechanisms can largely benefit from increased attention from finance scholars. This paper and special issue are an attempt in this direction.
\end{abstract}

Keywords Equity crowdfunding $\cdot$ Entrepreneurial finance $\cdot$ Corporate finance . Crowdfunding

JEL Classification L26 · G29

\section{Introduction}

Equity crowdfunding has emerged as an attractive funding route for entrepreneurial ventures, with $\$ 1.52$ billion raised globally in 2020 (Cambridge Centre of Alternative Finance, 2021). However, while this phenomenon has attracted the attention of management and entrepreneurship scholars, only a few corporate finance papers have so far focused on equity crowdfunding. Recently, Butticè and Vismara (2021) consider the entire equity crowdfunding process and all the actors involved to discuss the potential and the perils of equity crowdfunding for inclusivity and democratization and provide first insights on the industrial dynamics in equity crowdfunding. As a follow-up, this paper looks at equity crowdfunding using the lenses of corporate finance. Equity crowdfunding markets lie indeed at the crossroad between public equity and private equity. In equity crowdfunding, firms raise capital online from a large pool of heterogeneous investors, thereby providing primary market opportunities similar to traditional public markets, such as initial public

Silvio Vismara

silvio.vismara@unibg.it

1 Department of Management, University of Bergamo, Via dei Caniana, 2, 24127 Bergamo, Italy 
offerings (IPOs). The development of secondary markets is instead still limited, making the post-offering perspectives of both crowdfunding investors and firms closer to private equity deals. Table 1 positions equity crowdfunding between private and public equity. ${ }^{1}$

We first look at the stakeholders, distinguishing issuers, investors, and intermediaries. While public offerings are too expensive for most entrepreneurs, equity crowdfunding is open to nonpublic firms in traditional sectors. Business models should, however, not be overly complex as investors have low incentives and capabilities to perform in-depth due diligence. On the contrary, not all businesses and industries satisfy the growth and exit preferences of private equity or venture capital (VC) firms. While private equity requires high levels of capital, typically invested by high net worth individuals, accredited and non-accredited investors both can access equity crowdfunding, though investment limits vary based on investor income/net worth. ${ }^{2}$ There are relevant differences in the degree of intermediation between equity crowdfunding and traditional markets. Private equity deals involve both disintermediated finance such as business angels and intermediated finance such as VCs. While VC and business angel financing are limited to a small group of sophisticated investors, equity crowdfunding allows issuers to advertise their securities directly to small investors. The understanding of their behavior is of interest as they are central to the function of this type of market and because they are likely to differ from traditional early-stage investors. In IPOs, money is invested directly from investors, with stock exchanges engaging in extensive due diligence (Link et al., 2021). Documents are vetted by national agencies (e.g. Securities and Exchange Commission). Money is invested directly from investors also in equity crowdfunding. However, investment information is easily and directly available online on the platform website, including videos and full business plans. These documents, however, are not vetted by national agencies and are subject to lighter due diligence as compared to IPO prospectuses. As an example, the Financial Times has defined as "pretty opaque" the 31-page document of a very successful crowdfunding offering that did not contain one set of financial metrics relating to the company. ${ }^{3}$ The level of regulation and investor protection in equity crowdfunding is a topic of strong interest for policymakers and academics. Hornuf and Schwienbacher (2017) argue that too strong investor protection in equity crowdfunding may harm small firms and entrepreneurial initiatives, which contrasts with the traditional "law and finance" view that stronger investor protection is better.

Equity crowdfunding can also provide important insights in terms of "theory transmigration". For instance, taking theories used to interpret IPOs or VC investments and translating them to the equity crowdfunding context. Information cascades are an example. Both in IPOs and equity crowdfunding, investors consider the signal provided by the bids of previous investors, especially if they are sophisticated investors. In IPOs, late investors alter their own valuations by observing the behavior of early investors (Aggarwal et al., 2002; Welch, 1992). This explains why IPOs typically result in either oversubscription or undersubscription, with very few cases in between. The same happens in equity crowdfunding. There are, however, some relevant differences between the two contexts. While

\footnotetext{
1 Table 1 is taken with permission from Rossi et al. (2021).

2 The requirements to raise capital through equity crowdfunding vary across jurisdictions and change over time. Hornuf and Schwienbacher (2017) discuss the level of regulation in equity crowdfunding discuss regulatory reforms in different countries and discuss how they may impact equity crowdfunding. Rossi and Vismara (2018) provide a comparison of the regulatory settings of equity crowdfunding in Europe.

3 https://ft.com/content/ef52897c-be08-334e-ba05-a6971ad64e67.
} 


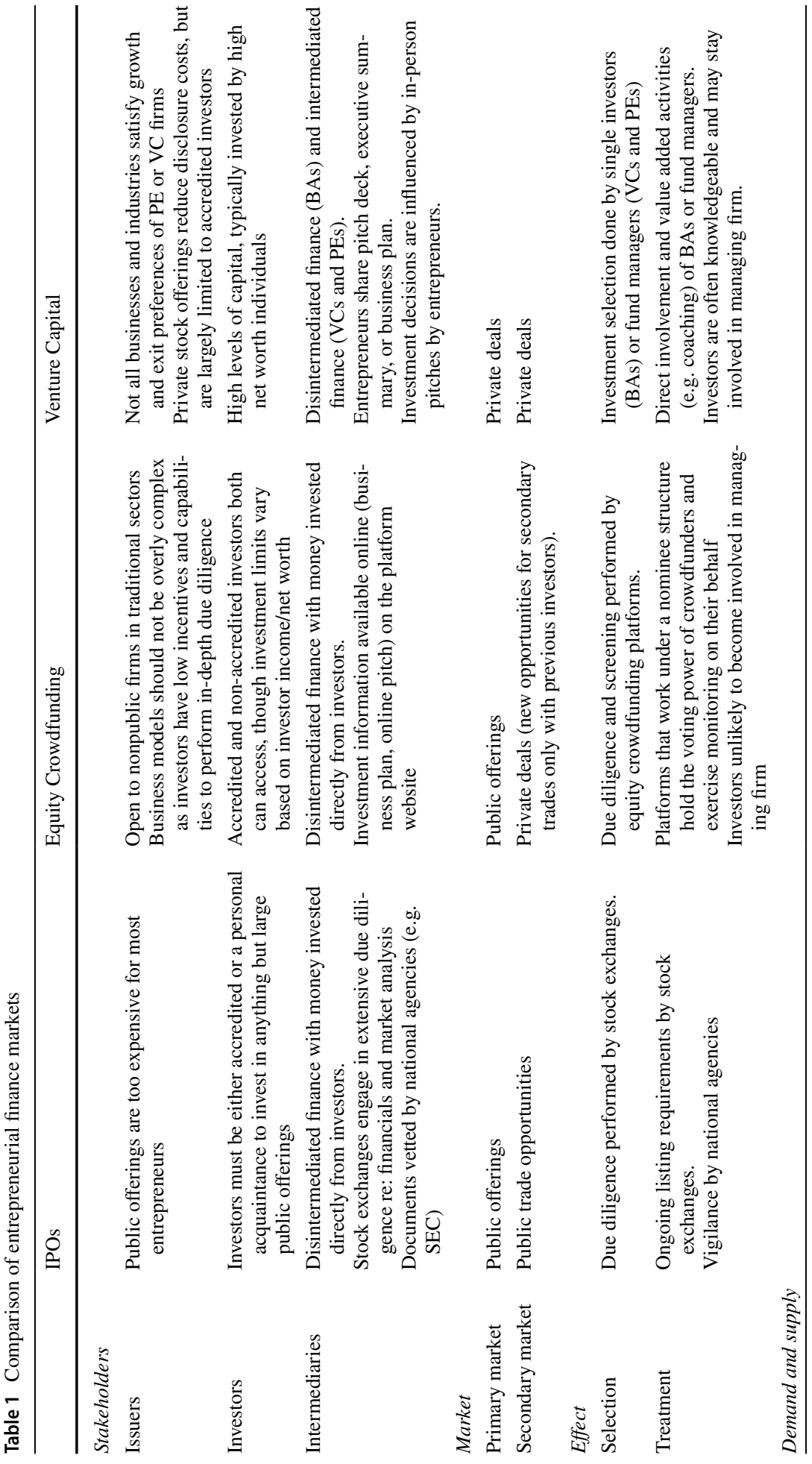




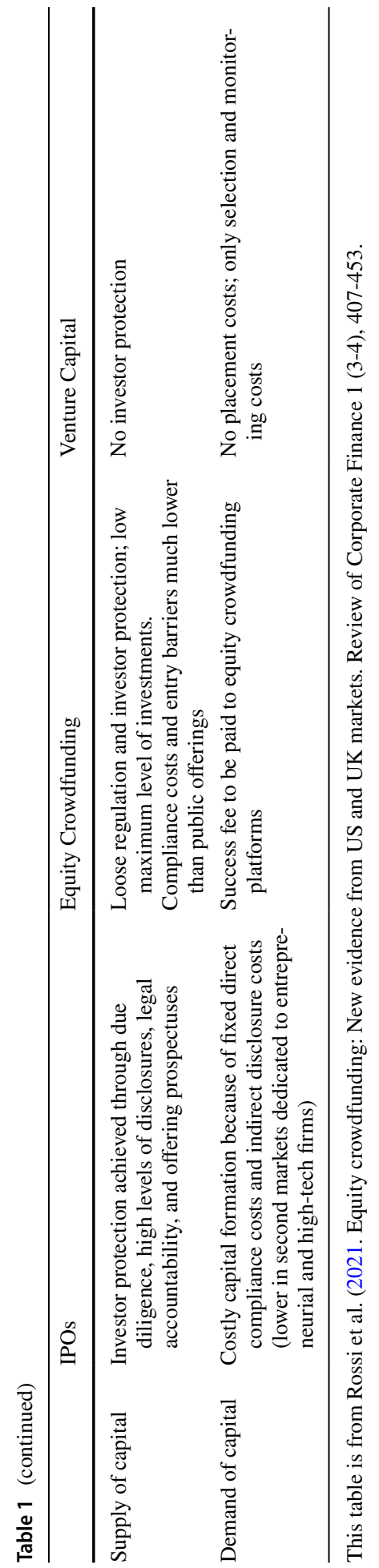

Springer 
the information available in IPOs about previous bids is limited to the distinction between institutional and retail investors, crowdfunding platforms often disclose more, including names of investors in each bid. Vismara (2018) uses this fine-grained information to document that sophisticated investors increase the appeal of the offer immediately among early investors, who in turn attract late investors. Future studies of investors' dynamics in equity crowdfunding can lead to a better understanding of how investors engage in public offerings.

This paper and the related special issue aim at expanding corporate finance perspectives to equity crowdfunding. In Sect. 2, we review a selection of papers on equity crowdfunding published in finance journals. Section 3 draws the main lines of this special issue. Section 4 concludes by offering considerations on the "new normal" of digital finance.

\section{Corporate finance studies on equity crowdfunding}

Four special issues in finance journals have so far considered equity crowdfunding in the context of digital finance. Bollaert et al. (2021) discuss the challenges of research in the digital finance area and propose avenues for future research. Farag and Johan (2021) look at disclosure, information asymmetry, and adverse selection, and how different alternative finance solutions are used to mitigate these issues. Among other aspects, they consider the role of control rights and show how their importance varies by context including equity crowdfunding alongside other types of alternative finance. Ahlstrom et al. (2018) focus on the corporate governance implications of new methods of entrepreneurial firm formation. Their rationale is that the emergence of equity crowdfunding has also given rise to unique concerns with information asymmetries between insiders and outsiders, along with related agency and other governance concerns. Since the reduction in communications costs due to technological innovation has made cross-border investments easier (e.g. reduced costs of monitoring investments over long distances), they call for future research on how globalization and technological innovation interact in their effect on crowdfunding (Ahlstrom et al., 2017). Finally, a special issue of the Review of Corporate Finance is dedicated to fintech. Within this special issue, Coakley et al. (2021b) provide a comprehensive review of the literature on equity crowdfunding, while Allen et al. (2021) deliver a survey of fintech research and discuss many related policy issues.

The topic within equity crowdfunding that has attracted most of the attention of finance scholars is the post-offering performance of equity crowdfunded firms. Signori and Vismara (2018) study what happens to firms that raise capital in equity crowdfunding platforms and find that $18 \%$ of these firms failed, while $35 \%$ pursued one or more seasoned equity offerings in the form of either private equity injection (9\%) or follow-on crowdfunding offering (25\%). Firms with more dispersed ownership are less likely to issue further equity, while those that reach the target capital more quickly are more likely to launch a follow-on offering. Interestingly, companies initially backed by qualified investors typically do not fail in the years immediately after the crowdfunding offering. Basing on a sample of equity crowdfunded firms matched with counterparts that did not raise any equity financing, Walthoff-Borm et al. (2018) find that equity crowdfunded firms have 8.5 times higher failure rates. They illustrate the differences between the nominee and direct shareholder structure in equity crowdfunding, finding that firms financed through a nominee make smaller losses, whereas those financed through a direct structure have more new patent applications. Hornuf et al. (2018) study equity crowdfunding in German and UK markets. 
They find that equity crowdfunded firms are more likely to obtain follow-on financing through business angels and VCs, but also have a higher likelihood to fail, compared to UK equity crowdfunded firms. The number of senior managers and the presence of professional investors in the initial equity crowdfunding offering has a positive impact on obtaining follow-on financing, whereas the average age of the senior management team has a negative impact. Coakley et al. (2021a) conjecture that, just as seasoned equity offering firms are likely to face fewer information asymmetry problems relative to IPO firms, the same applies to seasoned equity crowdfunding offerings relative to initial equity crowdfunding offerings. This is mainly due to new information at a seasoned - such as pre-money valuation gains - that reduces adverse selection problems. Butticè et al. (2020) provide evidence that equity crowdfunding has implications for firms long after the capital raised through the campaign is injected, in that a successful equity crowdfunding campaign facilitates the attraction of $\mathrm{VC}$ financing, especially for equity crowdfunding campaigns with a nominee shareholder structure.

A few finance studies focus on the dynamics among investors in equity crowdfunding. Hornuf and Schwienbacher (2018) investigate what determines individual investment decisions of investors in equity crowdfunding and find that dynamics are $\mathrm{L}$ shaped under a firstcome, first-served mechanism and $\mathrm{U}$ shaped under a second-price auction. Crowdfunders base their decisions on information provided by the entrepreneur in the form of updates as well as by the investment behavior and comments of other crowd investors. Nguyen et al. (2019) find that the increase of funding activity in the final days of the offerings is pronounced when the levels of information asymmetry are high. Crowdfunding investors delay their investment decisions to reduce uncertainty by gaining new information about the quality of firms. Meoli and Vismara (2021) focus on the possibility provided to investors by equity crowdfunding markets, similarly to other digital finance markets, to withdraw their non-binding bids within a cooling-off period. As the bids are visible online, they argue that this option can be used to manipulate the information available to investors. Consistently, they observe frequent $(10.2 \%)$ investment withdrawals before the end of the offerings. Platform members very frequently invest in the offering listed on their own portal and are then 1.85 times more likely to withdraw than the average crowdfunding investor. Their investments take place predominantly in low-quality offerings and influence the campaign dynamics, increasing the number of subsequent bids. Hervé et al. (2019) find that equity crowdfunding investors with more daily social interactions invest more than others. The effect of social capital on investment decisions is stronger for equity crowdfunding than for bond crowdfunding. Female investors invest less in equity investments but more in bonds. Shafi and Mohammadi (2020) find that a change in sky cloud cover from zero to full reduces the contribution amount of crowdfunding investors, thereby highlighting the broader role of financiers' moods and emotions in providing valuable financial resources to entrepreneurs.

Other finance studies have focused on the characteristics of crowdfunding offerings. Rossi et al. (2021) study the full population of initial equity crowdfunding offerings in the UK and US markets from 2012 to 2019. Excluding 81 offerings that are mini-bonds, convertibles, or fund campaigns and 812 equity offerings conducted by entrepreneurial ventures that had already launched an equity crowdfunding offering on Crowdcube, Seedrs, or SyndicateRoom platforms, they identify a final sample of 2,959 offerings. They find that, in all markets, higher equity retention by original entrepreneurs positively affects the chances of success of the offerings and the amount of capital raised. However, there are differences across platforms. Patents do not have a significant impact on entrepreneur-led platforms, while they matter in the UK investor-led platform SyndicateRoom. By separately observing 
the capital demand set by entrepreneurs and the capital supply by investors, they find that entrepreneurs in financial centers set higher targets in UK markets. There is no difference in the amount of capital raised by female and male entrepreneurs, conditional on female founders setting lower targets in UK markets. Hornuf et al. (2021a) investigate the relevance of cash-flow, control, and exit rights awarded to crowd investors in Germany, where more flexible contracts are offered than in many other jurisdictions. They find that crowd investors are asked to pay higher prices if they receive more cash-flow and exit rights, consistent with the view that these rights are valuable to the crowd. However, they find no evidence that these rights affect campaign outcome, the likelihood of securing follow-on funding, or the insolvency likelihood of the venture. Johan and Zhang (2020) study the impact of qualitative business information on mitigating information asymmetry between equity crowdfunding entrepreneurs and investors. They find that more detailed disclosure of qualitative business information leads to better fundraising outcomes, while entrepreneurs' excessive use of promotional language, or self-praise on business quality without factual support, is not rewarded by sophisticated investors.

From a different perspective, a few studies have focused on crowdfunding platforms rather than offerings. Cumming et al. (2019) document large heterogeneity in the due diligence activities of crowdfunding platforms. Due diligence is associated with a higher percentage of successful campaigns, more fund contributors, and a larger amount of capital raised on platforms. Meoli et al. (2021) find higher platforms' survival profiles where the level of financial literacy is high. Financial literacy, however, needs to combine with specific platform characteristics to take full effect, as it matters more to those platforms that deliver voting rights and that provide poorer value-added services to crowdfunding investors.

\section{Synopsis of the articles in this special issue}

Cumming et al. (2021a) compare equity crowdfunding to other types of digital finance markets. Traditional intermediaries have the ability and the incentive to intertemporarily smooth outcomes. Fintechs, such as peer-to-peer (P2P) lending platforms and equity crowdfunding platforms, enable riskier projects without regard to intertemporal smoothing. They examine the relationship between aggregate equity crowdfunding, P2P lending, and consumer bank loans. In particular, they focus on the comparative impact of COVID-19 on each funding type. The paper is built on the expectation that banks with sophisticated managers anticipate in advance the negative economic impact of COVID-19 and, as a result, decrease loan amounts prior to the crisis to better smooth loans intertemporally. Using U.S. data from May 2016 to June 2020, they show that COVID-19 harmed bank consumer lending. However, digital finance markets are more stable, timely, and resilient in the COVID19 crisis compared to bank consumer lending.

Coakley et al. (2021c) present new evidence on the implications of founder team characteristics for the choice of equity crowdfunding platform shareholder structures. This study employs firm and campaign data from Crowdcube, Seedrs and SyndicateRoom for the period from January 2013 to December 2018. The multinomial probit results suggest that founder teams are more likely to conduct campaigns on a platform that employs the coinvestment model. Less heterogeneous teams are more likely to choose a nominee account platform structure while the opposite holds for a platform with a co-investment approach. 
Cerpentier et al. (2021) apply corporate finance theories of market timing to equity crowdfunding markets. They argue that although equity crowdfunding shares some similarities with IPO markets, we cannot simply generalize what we know from prior finance work on the consequences of market timing for capital structure in new IPO firms to private equity crowdfunding firms. Accordingly, they provide first-time evidence on the impact of market timing for the capital structure of private firms that raised initial equity crowdfunding. With a sample of firms financed via either Crowdcube or Seedrs, they find that in hot markets equity crowdfunding firms set higher targets, accept more overfunding, and thus raise more equity capital than equity crowdfunding firms in cold markets. Surprisingly, however, and inconsistent with a market timing theory of capital structure, they fail to find differences between the leverage ratios of hot and cold market firms from the year of the equity crowdfunding campaign. This finding is explained by hot market firms contemporaneously rebalancing their capital structure by attracting more debt, especially financial debt.

Butticè et al. (2021) compare a large dataset of companies that successfully raised funds on UK equity crowdfunding platforms with a control group of firms financed by business angels to investigate whether and how having successfully run a crowdfunding offering is associated with the reputation of follow-on VC investors attracted. They find that crowdfunded companies are associated with lower-reputation VCs. This evidence is consistent with the idea that crowdfunding is perceived as a second-order signal, compared to the reception of seed financing from other traditional sources. Besides these interesting findings, this paper provides a timely summary of 23 studies using UK equity crowdfunding as the empirical setting. This testifies the relevance of the UK setting to the literature on equity crowdfunding and offers a good reference to grasp the results of previous studies.

Johan and Zhang (2021) investigate equity crowdfunding from an innovative angle by examining differences in effective signaling amongst crowdfunding start-ups based on their industry classification. They present new evidence revealing differences in startup characteristics across various industry sectors and examine how certain startup characteristics influence business valuations for representative industries in equity crowdfunding. They also build a business valuation mechanism to how valuation is influenced by start-up characteristics in representative industry sectors, based on the evidence that investors focus on different business aspects for equity crowdfunding firms in different sectors.

Kleinert and Mochkabadi (2021) contribute to an improved understanding of the democratization that equity crowdfunding, and more broadly digital finance, is expected to bring to entrepreneurial finance markets (Cumming et al. 2021b). Drawing on signaling and gender role congruity theory, they show that quality signals have different effects depending on whether they are sent by male or female entrepreneurs. Indeed, while management experience is beneficial for male entrepreneurs but detrimental for female entrepreneurs, vice versa media coverage has more impact as a third-party signal for female entrepreneurs.

Hornuf et al. (2021b) deliver new insights into how personal experience affects investment decisions. They indeed find that the experience of default changes the willingness to make new investments, but this effect depends on the respective investor type. Specifically, they study how investor motives affect crowdfunders by focusing on sustainability-oriented investors in Germany and Austria. They find that sustainability-oriented investors pledge larger amounts of money and invest in more offerings than other investors. Sustainabilityoriented investors consider non-financial returns as they react more sensitively after experiencing a default in their equity crowdfunding portfolios.

Last, Belitski and Boreiko (2021) expand the perspective to consider the related field of blockchain finance, dealing with initial coin offerings (ICO). Building on the equity 
crowdfunding literature, they outline the peculiarities of the ICO context, which provide initial insights into the potential motives and drivers for ICO investments and what characteristics of the ICO could serve as positive signals for potential ICO investors. Using novel data on 374 token sales and more than 300,000 contributions, they identify three boundary conditions that predict ICO fundraising amount, number of investors, hard cap achievement and token ranking. These are registering ICO and publishing project's code on GitHub, obtaining VC or business angel financing before the campaign or during the presale, and finally, publishing the whitepaper before the campaign's start.

\section{Conclusions}

We believe that equity crowdfunding has many similarities and differences related to traditional types of entrepreneurial finance markets that make it a privileged setting for investigation. At the same time, we believe that corporate finance has the potential to better our understanding of the mechanisms of equity crowdfunding. This paper and the related special issue are meant to contribute to expanding the corporate finance perspective to equity crowdfunding. Equity crowdfunding and digital or blockchain finance might indeed become even more relevant in the near future.

With the COVID-19 crisis preventing many companies from meeting legal and regulatory obligations, the mechanisms of raising capital are changing. Since 2005, more than 30,000 companies have been delisted from stock markets globally. These delistings have not been matched with new listings, resulting in a net loss of listed companies. At the same time, however, the number of special-purpose acquisition companies (SPACs) has recently dramatically increased (Gahng et al., 2021). While a growing amount of money is being allocated to a diminishing number of companies and the resulting re-concentration of ownership in the hands of large institutional investors, the rapid migration to digital technologies driven by the pandemic will likely continue into the "new normal". Equity crowdfunding, but also peer-to-peer lending and blockchain finance, has spread globally. These digital finance platforms allow for direct fundraising from a pool of online backers and will need to cope with collective-action problems as crowd-investors have neither the ability nor the incentive, due to the small investments, to devote substantial resources to due diligence. Retail trading has been accelerating over the last few years, but the pandemic brought new investors online, sometimes for the first time. Work-from-home, stimulus checks and higher personal savings levels, as well as social media platforms like Reddit or Robinhood, have accelerated the boom in retail investing. Since the start of 2020, retail trading as a share of overall activity has more than doubled, according to Credit Suisse. The GameStop bubble has come and gone but "we believe some of the new retail activity is here to stay," wrote an analytics team at Bank of America in a report to clients. As the retail investing footprint grows, the above-mentioned collective action problems are likely to limit investors' monitoring incentives. Entrepreneurs and managers can be tempted to shirk and engage in selfdealing. The perspective of corporate finance is needed to address the perhaps opposing trends of ownership concentration and retail investing.

Acknowledgements I owe great gratitude to Al Link whose guidance and support were invaluable over the past years. Vincenzo Butticè, Michele Meoli, Alice Rossi, and Tom Vanacker for helpful comments on an earlier draft. I am grateful to the following individuals for sharing their time and expertise to help develop this special issue of Journal of Technology Transfer by reviewing the papers and commentaries submitted: Maksim Belitski, Vincenzo Butticè, Jerry Coakley, Douglas Cumming, Lars Hornuf, Sofia Johan, 
Simon Kleinert, Michele Meoli, Kazem Mochkabadi, Alice Rossi, Andrea Signori, Tom Vanacker and Yelin Zhang.

\section{References}

Aggarwal, R., Prabhala, N. R., \& Puri, M. (2002). Institutional allocation in initial public offerings: Empirical evidence. Journal of Finance, 57(3), 1421-1442

Ahlstrom, D., Cumming, D. J., \& Vismara, S. (2017). Corporate governance implications of new methods of entrepreneurial firm formation. Corporate Governance: An International Review, 25(1), 41-57. https://doi.org/10.1111/corg.12189.

Ahlstrom, D., Cumming, D. J., \& Vismara, S. (2018). New methods of entrepreneurial firm financing: Fintech, crowdfunding and corporate governance implications. Corporate Governance: An International Review, 26(5), 310-313. https://doi.org/10.1111/corg.12258.

Allen, F., Gu, X., \& Jagtiani, J. (2021). A Survey of Fintech Research and Policy Discussion. Review of Corporate Finance, 1(3-4), 259-339

Belitski, M., \& Boreiko, D. (2021). Success Factors of Initial Coin Offerings. Journal of Technology Transfer (in press)

Bollaert, H., Lopez-de-Silanes, F., \& Schwienbacher, A. (2021). Fintech and access to finance. Journal of Corporate Finance, 68, 101941. https://doi.org/10.1016/j.jcorpfin.2021.101941

Butticè, V., Di Pietro, F., \& Tenca, F. (2020). Is equity crowdfunding always good? Deal structure and the attraction of venture capital investors. Journal of Corporate Finance, 65, 101773. https://doi.org/10. 1016/j.jcorpfin.2020.101773

Butticè, V., Di Pietro, F., \& Tenca, F. (2021). They Do Not Look Alike: What Kind of Private Investors Do Equity Crowdfunded Firms Attract? Journal of Technology Transfer (in press).

Butticè, V., \& Vismara, S. (2021). Inclusive digital finance: the industry of equity crowdfunding. The Journal of Technology Transfer. https://doi.org/10.1007/s10961-021-09875-0

Cambridge Centre for Alternative Finance The 2nd Global Alternative Finance Market Benchmarking Report. https://www.jbs.cam.ac.uk/faculty-research/centres/alternative-finance/publications/the-2ndglobal-alternative-finance-market-benchmarking-report/

Cerpentier, M., Vanacker, T., Paeleman, I., \& Bringman, K. (2021). Equity Crowdfunding, Market Timing, and Firm Capital Structure. Journal of Technology Transfer(in press).

Coakley, J., Lazos, A., \& Liñares-Zegarra, J. M. (2021a). Seasoned equity crowdfunded offerings. Journal of Corporate Finance. https://doi.org/10.1016/j.jcorpfin.2020.101880101880

Coakley, J., Lazos, A., \& Liñares-Zegarra, J. (2021b). New developments in equity crowdfunding: A review. Review of Corporate Finance, 1(3-4), 341-405

Coakley, J., Lazos, A., \& Liñares-Zegarra, J. (2021c). Strategic entrepreneurial choice between competing crowdfunding platforms.Journal of Technology Transfer(in press).

Cumming, D. J., Johan, S. A., \& Zhang, Y. (2019). The role of due diligence in crowdfunding platforms. Journal of Banking \& Finance, 108, 105661. https://doi.org/10.1016/j.jbankfin.2019.105661

Cumming, D. J., Martinez-Salgueiro, A., Reardon, R., \& Sewaid, A. (2021a). COVID-19 Bust, Policy Response, and Rebound: Equity Crowdfunding and P2P vs. Banks. Journal of Technology Transfer(in press).

Cumming, D. J., Meoli, M., \& Vismara, S. (2021b). Does equity crowdfunding democratize entrepreneurial finance? Small Business Economics, 56, 533-552. https://doi.org/10.1007/s11187-019-00188-Z

Farag, H., \& Johan, S. (2021). How alternative finance informs central themes in corporate finance. Journal of Corporate Finance, 67, 101879. https://doi.org/10.1016/j.jcorpfin.2020.101879

Gahng, M., Ritter, J. R., \& Zhang, D. (2021). SPACs. SSRN Electronic Journal. https://doi.org/10.2139/ Ssrn.3775847

Hervé, F., Manthé, E., Sannajust, A., \& Schwienbacher, A. (2019). Determinants of individual investment decisions in investment-based crowdfunding. Journal of Business Finance \& Accounting, 46(5-6), 762-783. https://doi.org/10.1111/jbfa.12372

Hornuf, L., Schilling, T., \& Schwienbacher, A. (2021a). The relevance of investor rights in crowdinvesting. Journal of Corporate Finance. https://doi.org/10.1016/j.jcorpfin.2021.101927101927

Hornuf, L., Schmitt, M., \& Stenzhorn, E. (2018). Equity crowdfunding in Germany and the United Kingdom: Follow-up funding and firm failure. Corporate Governance: An International Review, 26(5), 331-354. https://doi.org/10.1111/corg.12260

Hornuf, L., \& Schwienbacher, A. (2017). Should securities regulation promote equity crowdfunding? Small Business Economics, 49, 579-593 
Hornuf, L., \& Schwienbacher, A. (2018). Market mechanisms and funding dynamics in equity crowdfunding. Journal of Corporate Finance, 50, 556-574. https://doi.org/10.1016/j.jcorpfin.2017.08.009

Hornuf, L., Stenzhorn, E., \& Vintis, T. (2021b). Are Sustainability-Oriented Investors Different? Evidence from Equity Crowdfunding. Journal of Technology Transfer(in press).

Johan, S., \& Zhang, Y. (2021). Investors' Industry Preference in Equity Crowdfunding. Journal of Technology Transfer (in press).

Johan, S., \& Zhang, Y. (2020). Quality revealing versus overstating in equity crowdfunding. Journal of Corporate Finance, 65, 101741. https://doi.org/10.1016/j.jcorpfin.2020.101741

Kleinert, S., \& Mochkabadi, K. (2021). Gender stereotypes in equity crowdfunding: the effect of gender bias on the interpretation of quality signals. Journal of Technology Transfer(in press).

Link, A. N., van Hasselt, M., \& Vismara, S. (2021). Going public with public money. Small Business Economics, 57, 1419-1426. https://doi.org/10.1007/s11187-020-00355-7.

Meoli, M., \& Vismara, S. (2021). Information manipulation in equity crowdfunding markets. Journal of Corporate Finance, 67, 101866. https://doi.org/10.1016/j.jcorpfin.2020.101866

Meoli, M., Vismara, S., \& Rossi, A. (2021). Financial Literacy and Security-based Crowdfunding. Corporate Governance: An International Review, 1-28. https://doi.org/10.1111/corg.12355

Nguyen, T., Cox, J., \& Rich, J. (2019). Invest or regret? An empirical investigation into funding dynamics during the final days of equity crowdfunding campaigns. Journal of Corporate Finance, 58, 784-803. https://doi.org/10.1016/j.jcorpfin.2019.07.011

Rossi, A., Vanacker, T. R., \& Vismara, S. (2021). Equity Crowdfunding: New Evidence From Us and UK Markets. Review of Corporate Finance, 1, 407-453. https://doi.org/10.1561/114.00000009

Rossi, A., \& Vismara, S. (2018). What do crowdfunding platforms do? A comparison between investment-based platforms in Europe. Eurasian Business Review, 8(1), 93-118. https://doi.org/10.1007/ s40821-017-0092-6.

Shafi, K., \& Mohammadi, A. (2020). Too gloomy to invest: Weather-induced mood and crowdfunding. Journal of Corporate Finance, 65, 101761. https://doi.org/10.1016/j.jcorpfin.2020.101761

Signori, A., \& Vismara, S. (2018). Does success bring success? The post-offering lives of equity-crowdfunded firms. Journal of Corporate Finance, 50, 575-591. https://doi.org/10.1016/j.jcorpfin.2017.10. 018

Vismara, S. (2018). Information cascades among investors in equity crowdfunding. Entrepreneurship Theory and Practice, 42(3), 467-497. https://doi.org/10.1111/etap.12261

Walthoff-Borm, X., Vanacker, T., \& Collewaert, V. (2018). Equity crowdfunding, shareholder structures, and firm performance. Corporate Governance: An International Review, 26(5), 314-330. https://doi. org/10.1111/corg. 12259

Welch, I. (1992). Sequential sales, learning, and cascades. Journal of Finance, 47, 695-732

Publisher's Note Springer Nature remains neutral with regard to jurisdictional claims in published maps and institutional affiliations. 